\title{
BIO-OPTICAL RETRIEVAL ALGORITHM FOR THE OPTICALLY SHALLOW WATERS OF LAKE MICHIGAN. II. EFFICIENCY ASSESSMENT
}

\author{
A. A. Korosov', D. V. Pozdnyakovi,2, R. Shuchman ${ }^{3}$, M. Sayers ${ }^{3}$, \\ R. Sawtell ${ }^{3}$, A. V. Moiseev ${ }^{2}$ \\ ${ }^{1}$ Nansen Environmental and Remote Sensing Center, Bergen, Norway \\ ${ }^{2}$ Scientific foundation "Nansen International Environmental and Remote Sensing Centre", \\ St. Petersburg, Russia \\ ${ }^{3}$ Michigan Tech Research Institute, Ann Arbor, USA
}

\begin{abstract}
With the exception of a few areas, Lake Michigan (LM) is an oligotrophic clear water body. It is predominantly in its littoral zone where ecology-relevant processes unfold due to a variety of natural and anthropogenic forcings arising from the watershed. However, the bottom influence there is strong enough to contaminate the at-satellite signal, thus impeding the remote sensing of water quality parameters within the coastal zone. A new bio-optical retrieval algorithm, based on a forward radiation transfer model, LM specific hydro-optical model and the multivariate optimization technique is developed for operational retrieval from satellite data of water quality parameters in lake optically shallow areas. Application of the developed operational tool to processing MODIS-Aqua data (matching up the location and timing of in situ CPA and radiometric measurements) has convincingly shown its advantage over the OC4 performance in lacustrine optically shallow waters at all sampling stations.
\end{abstract}

Ke y w ord s: optical remote sensing; spectral reflectance; attenuation; surface albedo; optically shallow waters; limnology; Lake Michigan.

\section{А. А. Коросов, Д. В. Поздняков, Р. Шухман, М. Сэйерс, Р. Сотелл, А. В. МОИСеев. БИО-ОПТИЧЕСКИЙ АЛГОРИТМ ДЛЯ ОПТИЧЕСКИ МЕЛКИХ ВОД ОЗЕРА МИЧИГАН. ІІ. ОЦЕНКА ЕГО ЭФФЕКТИВНОСТИ}

За исключением нескольких областей озеро Мичиган (ОМ) является олиготрофным водоемом с чистой и прозрачной водой. Вследствие воздействия́ природных и антропогенных процессов, происходящих на водосборной территории, экологически наиболее серьезные процессы разворачиваются прежде всего в литоральной зоне. В мелководной ее части оптическое влияние дна на сигнал, регистрируемый спутниковым датчиком, оказывается достаточно сильным, что затрудняет дистанционное зондирование параметров качества воды в этих районах. Разработанный для оперативного восстановления параметров качества воды в оптически мелких водах новый био-оптический алгоритм основан на модели переноса излучения, мо- 
дели оптических свойств вод ОМ и методе многомерной оптимизации. Применение разработанного алгоритма для обработки данных MODIS-Aqua убедительно показало преимущество нового алгоритма по сравнению со стандартным алгоритмом OC4 в случае оптически мелких вод.

Ключевые слова: оптическое дистанционное зондирование; спектральное отражение; альбедо поверхности; оптически мелкие воды; лимнология; озеро Мичиган.

\section{Introduction}

In this study of Lake Michigan's peripheral zone, we developed a multiband Bio-Optical REtrieval ALgorlthm for Optically Shallow Waters coined BOREALI-OSW. A detailed description of the novel algorithm is given in the first part of the present publication [Korosov et al., 2016].

The algorithm retrieves CPA concentrations from remote sensing reflectance in clear waters for a variety of bottom depths and bottom types. It is an extension of the BOREALI algorithm that has been previously developed for optically deep and turbid waters, went through thorough verification campaigns [Korosov et al., 2009] and proved its efficiency for a wide variety of water bodies including the North European and North American Great Lakes, among the latter - Lake Michigan [Shuchman et al., 2006].

Importantly, the BOREALI algorithm permits simultaneous retrieval of the concentrations of three ecologically important water quality constituents, viz. phytoplankton chlorophyll, suspended minerals and dissolved organic matter.

In the second part we are reporting on the assessment of the developed algorithm efficiency. This is done through a series of comparisons of retrieval results of the chlorophyll concentration $(\mathrm{CHL})$ with concurrent in situ $\mathrm{CHL}$ measurements. In the absence of in situ CHL determinations, the algorithm efficiency is proved through radiometric analysis of the spectral features of remote sensing reflectance, $R_{r s}(\lambda)$.

\section{Description of field measurements and station locations}

Field campaigns were conducted in 2012 and 2013 employing one and the same set of instrumentation. Field measurements (for study locations see Fig. 1) of optical parameters included spectral measurements in the visible of: (i) downwelling irradiance $\left(\mathrm{W} \mathrm{m}^{-2}\right)$ and (ii) upwelling radiance $\left(\mathrm{W} \mathrm{m}^{-2} \mathrm{sr}^{-1}\right)$ immediately above $(0+)$ and below (0-) the water surface as well as at about 1 meter depth.
Field optical measurements were collected using an Analytical Spectral Devices, Inc., (ASD) FieldSpec spectroradiometer operating within the spectral range $350-2500 \mathrm{~nm}$ at a spectral resolution not worse than $3 \mathrm{~nm}$. The signal-tonoise ratio within the visible is reportedly between 1000 and 10,000 at $400 \mathrm{~nm}$ and $500-700 \mathrm{~nm}$, respectively (http://www.asdi.com/products/ fieldspec-spectroradiometers). All measurements were made using a 5 meter optical jumper cable connecting the fore-optic to the spectrometer. The downwelling irradiance measurements were collected using a 180 degree Remote Cosine Receptor underwater fore-optic which collects $2 \pi$ diffuse irradiance. Upwelling radiance was measured using a 10B field-of-view fore-optic. Irradiance and radiance measurements were collected by connecting the optic to the end of a 3 meter long sampling pole to ensure that optical measurements be not affected by reflectance from the research vessel.

Periodic spectro-radiometer calibration runs were performed at the laboratory using a Spectralon (100 runs if there was significant sensor drift). The absence of significant differences between these measurements confirmed that the instrument remained in acceptable calibration state during the entire 2012-2013 field campaign.

At each site the irradiance measurement was made first. This measurement consists of 20 individual spectra measured at 1 second intervals. Each individual spectrum is an average of 10 radiometric counts, which is applied within the ASD RS3 software at the time of date collection. The radiance measurements were then made using the same procedure. The total time for the radiometric measurement sequence (irradiance followed by radiance) at each site was approximately 5 minutes. The days in which radiometric measurements occurred were specifically chosen, in part, because of the very stable atmospheric conditions exhibited, which helped to ensure minimal atmospheric variation within the 5 minute radiometric measurement sequence. Post-processing steps included averaging the 20 individual spectra for each measurement to produce single average spectra 


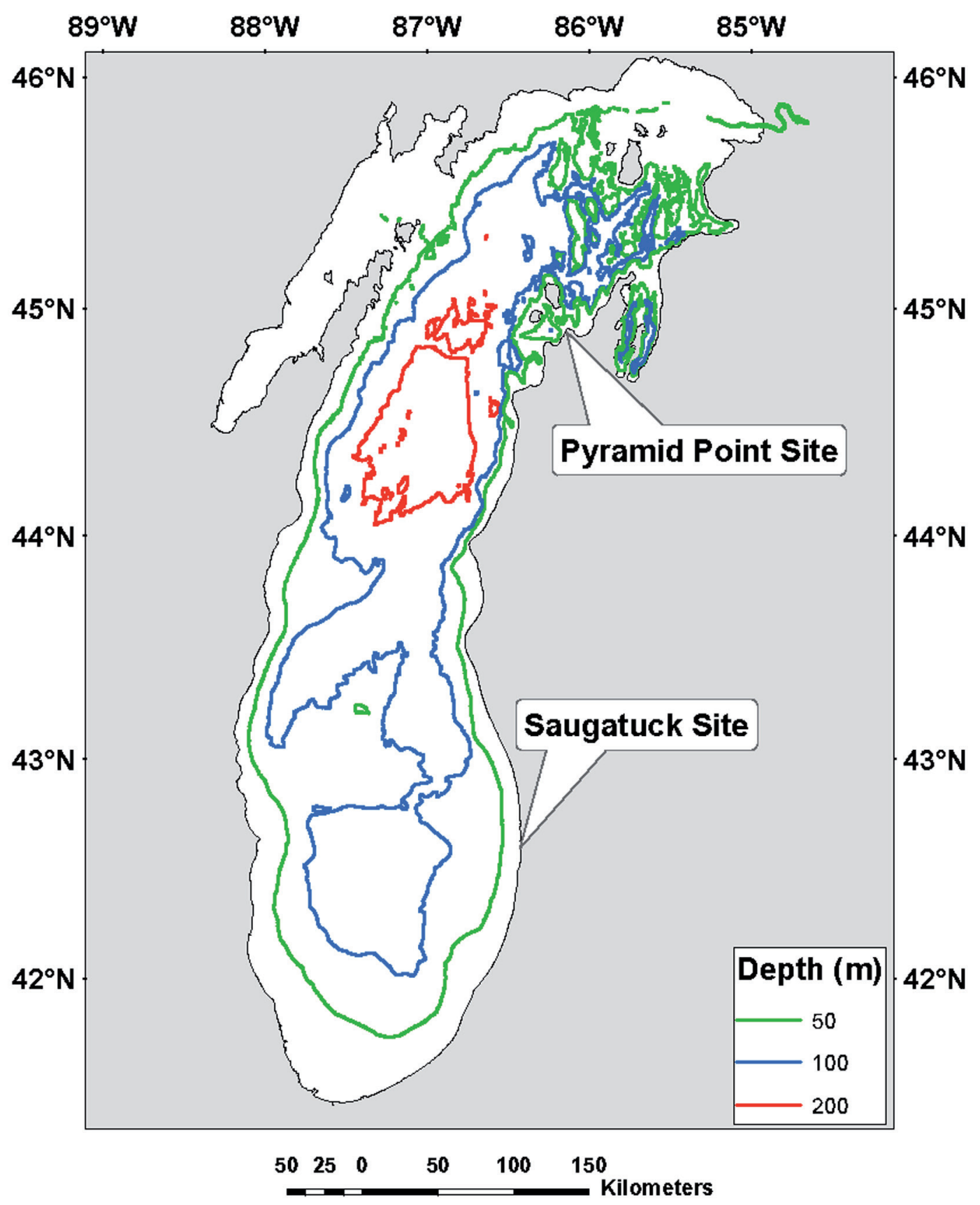

Fig. 1. Lake Michigan bathymetry and study site locations

of irradiance and radiance at each site. Measured values of downwelling irradiance and upwelling radiance were corrected for the immersion factor $\left(I_{f}\right)$, which accounts for the difference between the inair and in-water absolute response of submersible radiometers [Hooker, Zibordi, 2005; Zibordi, 2006].

Wave focusing was not taken into account in our optical measurement protocol, however, there were only very light winds $\left(\leqslant 2 \mathrm{~m} \mathrm{~s}^{-1}\right)$ reported in the vicinity of our sampling locations for the dates when measurements were made. Thus the overall effect of wave focusing on our spectra was assumed negligible.
Bottom cover types were ascertained using a Marcum underwater viewing system drop camera (http://casanovasadventures.com/catalog/watersports/p41910.htm. UnycnJFeHwl).

Spectrometric measurements nearby the Kalamazoo River Plume in eastern Lake Michigan were conducted in 2012 under mostly clear sky conditions with only small cumulus clouds in the periphery of the sky dome above the sampling stations (Fig. 2). Wave conditions were 0.5 meters or less for the mission. All instrumentation was deployed aboard the $17 \mathrm{ft} \mathrm{R} / \mathrm{V}$ Husky Traveler.

The $\mathrm{CHL}$ concentrations were estimated in the field using a Turner Designs AquaFluor 
Table 1. Data collected at each sampling point for the August 28, 2012 data collection

\begin{tabular}{c|c|c|c|c|c|c}
\hline $\begin{array}{c}\text { Station } \\
\text { Name }\end{array}$ & Lat., ${ }^{\circ} \mathrm{N}$ & Long., ${ }^{\circ} \mathrm{E}$ & $\begin{array}{c}\text { Sampling Time } \\
(\mathrm{EDT})\end{array}$ & Water Depth, $\mathrm{m}$ & $\mathrm{CHL}, \mathrm{mg} \mathrm{m}^{-3}$ & Bottom Type \\
\hline $\mathrm{S} 1$ & 42.62658 & 86.23351 & $11: 27 \mathrm{AM}$ & 4.9 & & $\begin{array}{c}\text { Rocky/sparse } \\
\text { algae }\end{array}$ \\
\hline $\mathrm{S} 2$ & 42.62559 & 86.23817 & $11: 52 \mathrm{AM}$ & 8.5 & & Rock/algae \\
\hline S3 & 42.62386 & 86.2464 & $12: 10 \mathrm{PM}$ & 13.7 & 0.57 & Optically deep \\
\hline S4 & 42.62663 & 86.22969 & $12: 58 \mathrm{PM}$ & 2.1 & & Algae \\
\hline S5 & 42.62676 & 86.2299 & $1: 12 \mathrm{PM}$ & 2.4 & 0.41 & Sand \\
\hline S6 & 42.6272 & 86.22839 & $1: 33 \mathrm{PM}$ & 0.6 & & Sand \\
\hline S7 & 42.62671 & 86.23252 & $1: 47 \mathrm{PM}$ & 4.9 & & Sand \\
\hline S8 & 42.62737 & 86.23708 & $2: 10 \mathrm{PM}$ & 6.7 & & Sand \\
\hline S9 & 42.64528 & 86.23238 & $2: 36 \mathrm{PM}$ & 6.1 & 1.7 & Sand \\
\hline S10 & 42.66342 & 86.22227 & $3: 05 \mathrm{PM}$ & 6.4 & 4.4 & Sand \\
\hline S11 & 42.67293 & 86.21919 & $3: 30 \mathrm{PM}$ & 4.9 & 12.4 & Sand
\end{tabular}

Handheld Fluorometer. The Turner Designs regression equation is $0.0764 x$ assuring the value of the coefficient of determination $r^{2}$ not less than 0.99 . The sampling stations were designed to encompass several different bottom cover types (sand, submerged aquatic vegetation, rock) over various depth ranges. Fig. 2 is a map displaying the sampling stations overlaid on Bing imagery. The data collected at each station including sampling time, bottom type, and depth are shown in Table 1.

In 2013 the field measurements were also performed on September 25 from a $17 \mathrm{ft} \mathrm{R/V} \mathrm{Boston}$ Whaler anchored at each sampling station within the coastal zone of the Sleeping Bear Dunes National Lakeshore in the shallow waters just off Pyramid Point (Fig. 3). The study area was chosen due to the abundant availability of large sandy flats that are within the optical depth of satellite sensors. This area is also largely unaffected by river discharge or anthropogenic influence ensuring similar water characteristics at most sampling stations.

Table 2 summarizes the respective characterization of this part of our activities. The phytoplankton types identified at this station comprise green, and blue-green alga, diatoms, and cryptophyta with a significant prevalence of green algae, while

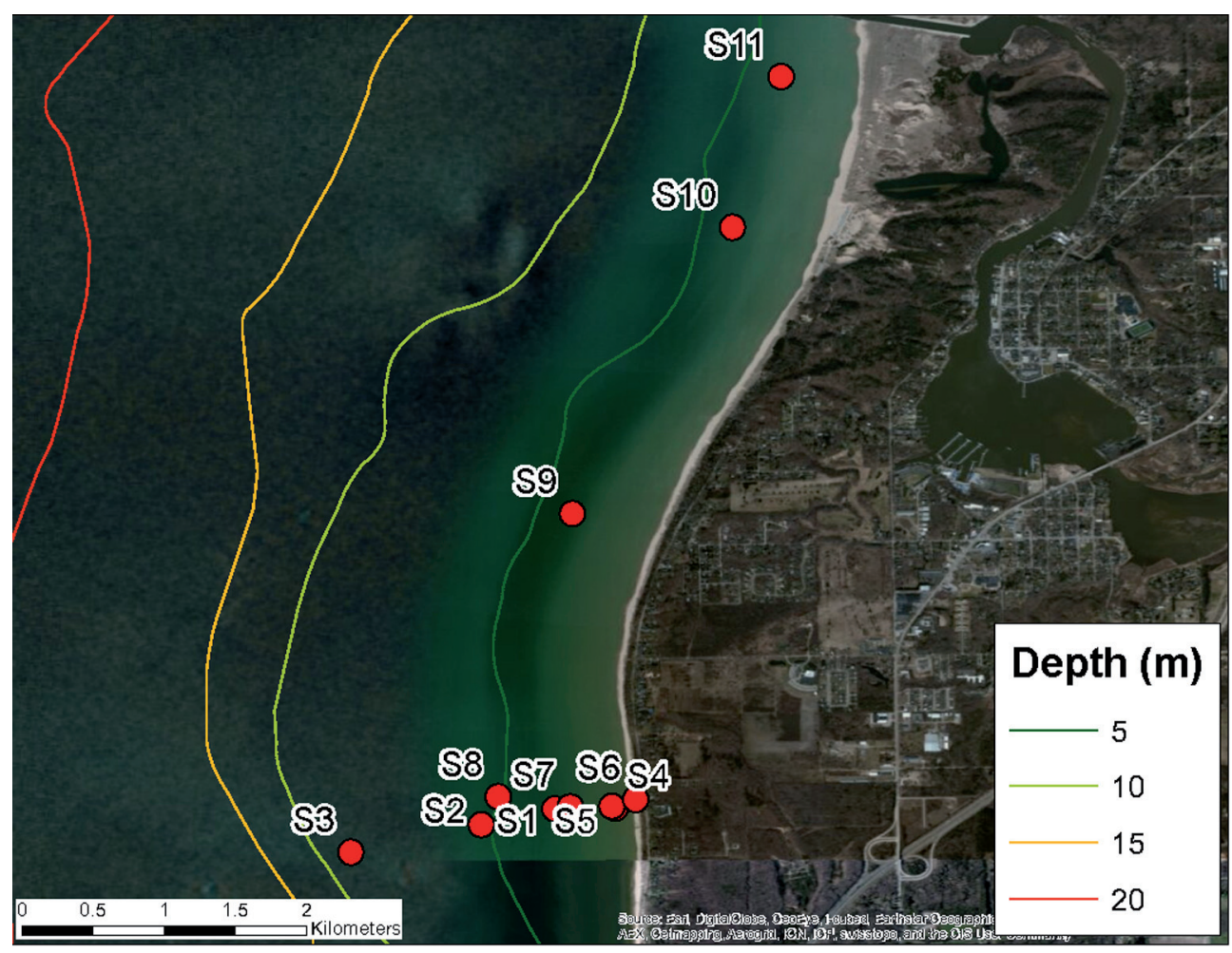

Fig. 2. Optical sampling locations and bathymetry for the August 28, 2012 Saugatuck, MI data collection. Note the background image is not coincident with the field collection 


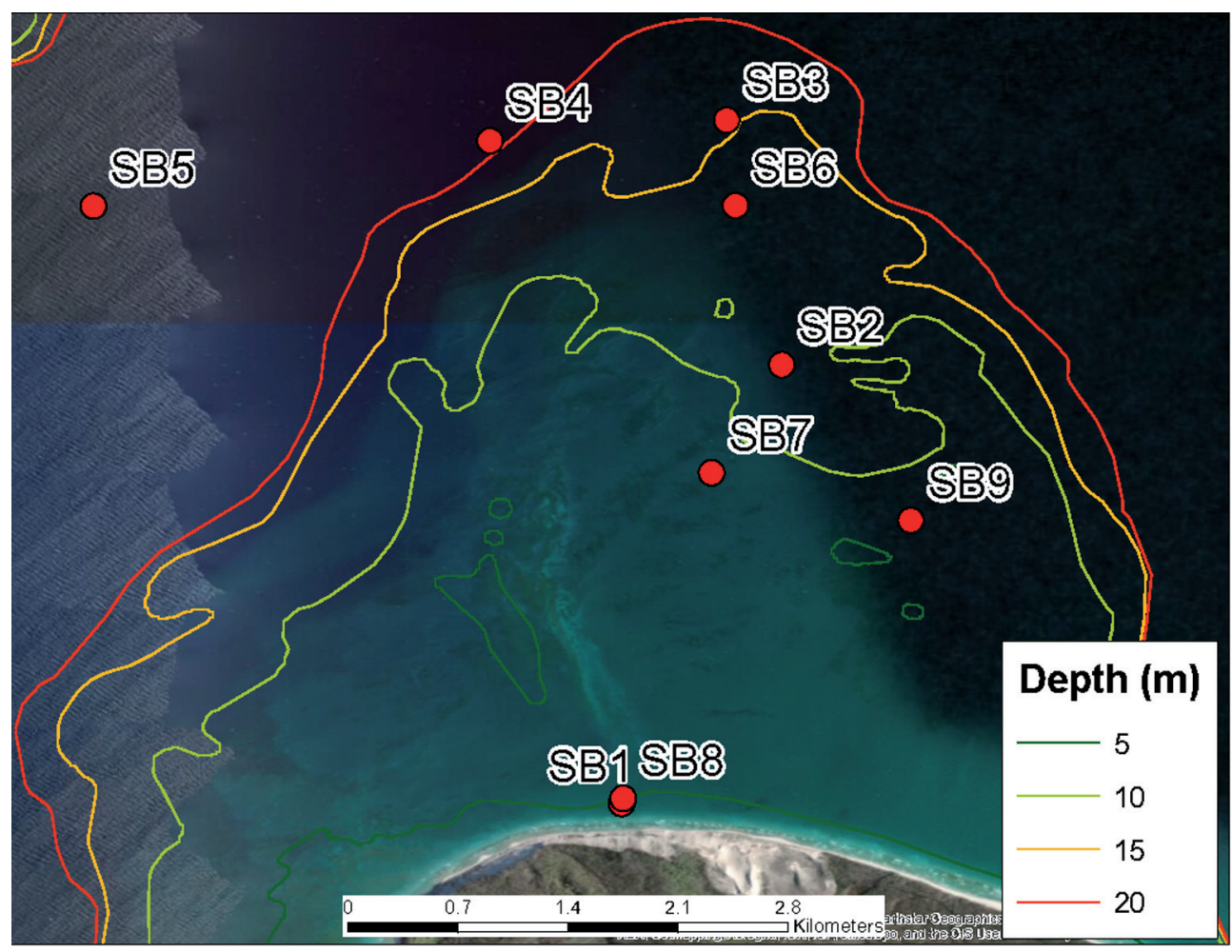

Fig. 3. Bathymetric features of the coastal zone off Pyramid Point, Sleeping Bear Dunes National Lakeshore, MI and the locations of stations sampled on September 25, 2013

diatoms constituted second highest cell numbers of the phytoplankton community. Sites SB1 and SB8 are in close proximity to each other as designed to test variable sun angle effects on bottom reflectance and to check up the consistency of measurement procedures. As Tables 1 and 2 indicate, the sampling period covered the time of sufficiently high solar elevations.

Thus in 2013 the sampling period began at approximately 10:30 am and ended at about 4:00 pm to ensure reasonable sunlight illumination conditions for aquatic remote sensing. In the course of both campaigns at each sampling station the field measurements also included determinations of Secchi depth, water temperature, cloud cover percentage, wave height, bottom type, and water depth.

At each station water samples were collected using a standard 5 liter Niskin bottle just below the water surface, therefore the collected water samples represent approximately the top 1 meter of the water column. Roughly 1 liter of water from the Niskin bottle was reserved to be filtered for chlorophyll-a pigment extraction, the remaining water was discarded. The 1 liter water samples were filtered in triplicate the day after collection onto filter pads and then frozen. After the filter pads had been frozen they were sent to Michigan Tech University where the chlorophyll-a extraction was completed using standard methods. These values are associated with the laboratory chlorophylla concentrations in the summary table. Although laboratory measurements of total suspended matter (TSM) would have been useful to establish a baseline value for particulates, the sheer volume of water necessary to provide a measureable amount of TSM in oligotrophic Lake Michigan was not feasible to obtain in the water craft used $(17 \mathrm{ft}$ $\mathrm{R} / \mathrm{V}$ Boston Whaler) in these sampling activities.

\section{Verification of the BOREALI-OSW algorithm}

Two sites in Lake Michigan were employed for the algorithm validation. Both are in close vicinity of the sandy beaches of the Sleeping Bear Dunes and Saugatuck city (Figs. 1-3). In both locations, the $\mathrm{CHL}$ concentration was measured at a number of spots/stations following the procedure described in Section 2.

For validation purposes two approaches were exploited. Firstly, we used our radiometric hydrooptical measurements of the subsurface remote sensing reflectance, $R_{\text {rSwTOT }}$ (subscript TOT implies the collective bottom and water column optical influence) in the spectral region 412-709 nm. However, because of fairly inaccurate radiometric numbers yielded by the employed instrumentation at the wavelengths in both violet and red spectral regions, in our verifications we only analyzed $R_{\text {rswTOT }}$ spectra between 443 and $620 \mathrm{~nm}$. 
Table 2. Characterization of the stations sampled on September 25, 2013 within the Sleeping Bear Dunes coastal zone

\begin{tabular}{c|c|c|c|c|c|c|c|c|c|c}
\hline $\begin{array}{c}\text { Station } \\
\text { Name }\end{array}$ & Lat, ${ }^{\circ} \mathrm{N}$ & Lon, ${ }^{\circ} \mathrm{E}$ & $\begin{array}{c}\text { Sampling } \\
\text { Time (EDT) }\end{array}$ & $\begin{array}{c}\text { Water } \\
\text { Depth, } \\
\mathrm{m}\end{array}$ & $\begin{array}{c}\mathrm{CHL}, \\
\mathrm{mg} \\
\mathrm{m}^{-3}\end{array}$ & Bottom Type & $\begin{array}{c}\text { Wave } \\
\text { Height, } \mathrm{m}\end{array}$ & $\begin{array}{c}\text { Secchi } \\
\text { Disk } \\
\text { Depth, } \mathrm{m}\end{array}$ & $\begin{array}{c}\text { Cloud } \\
\text { Cover, } \\
\%\end{array}$ & $\begin{array}{c}\text { Yellow } \\
\text { Substance }\end{array}$ \\
\hline $\mathrm{SB} 1$ & 44.97061 & 85.92645 & $10: 34-11: 11$ & 4.81 .76 & Sand & 0 & On Bottom & 10 & 0.07 & \\
\hline SB2 & 44.99574 & 85.91728 & $11: 25-11: 55$ & 9.8 & 1.45 & Sand & 0 & 32 & 15 & 0.09 \\
\hline SB3 & 45.00973 & 85.92043 & $12: 05-12: 34$ & 15 & 1.48 & Sand + Detritus & 0 & 47 & 15 & 0.05 \\
\hline SB4 & 45.00855 & 85.93399 & $01: 20-01: 48$ & 20.4 & 1.38 & Sand + Cladophora & 0.15 & 48 & 10 & 0.08 \\
\hline SB5 & 45.00481 & 85.95665 & $01: 52-02: 11$ & 56.8 & 1.39 & N/A & 0.15 & 47 & 10 & 0.09 \\
\hline SB6 & 45.00484 & 85.91994 & $02: 28-02: 45$ & 12.6 & 1.28 & Sand & 0.15 & 37 & 10 & 0.08 \\
\hline SB7 & 44.98955 & 85.92131 & $02: 50-03: 07$ & 7.4 & 1.34 & Sand & 0.23 & & 15 & 0.08 \\
\hline SB8 & 44.97091 & 85.92635 & $03: 16-03: 31$ & 5.1 & 1.58 & Sand & 0.3 & & 15 & 0.08 \\
\hline SB9 & 44.98681 & 85.90990 & $0.3: 48-04: 03$ & 5.8 & 1.77 & $\begin{array}{c}\text { Cobble + Fuzzy } \\
\text { Vegetation }\end{array}$ & 0.2 & & 10 & 0.1 \\
\hline
\end{tabular}

Secondly, we used MODIS-Aqua multispectral data at a resolution of $1 \times 1 \mathrm{~km}$ within the spectral region 412-678 $\mathrm{nm}$. By the analogous reasons, we spectrally truncated the MODIS-Aqua information leaving the spectral interval extending from 443 and $636 \mathrm{~nm}$ (the signal at $636 \mathrm{~nm}$ was interpolated between the two neighboring channels). The MODIS-Aqua satellite overpasses the region of interest in the time window from $2 \mathrm{pm}$ to $4 \mathrm{pm}$ local time (http://www-angler.larc.nasa.gov/cgibin/predict/predict.cgi), and the time difference between remote and in situ measurements (exact sampling time is given in Tables 1 and 2) can be up to 3-4 hours.

When retrieving the $\mathrm{CHL}$ concentration with the BOREALI-OSW algorithm from both radiometric and satellite data, we applied one and the same hydro-optical model developed specifically for Lake Michigan [Shuchman et al., 2013].

As indicated above, we have chosen the stations characterized by a presumably homogenous sandy bottom and clear waters rather essentially void of suspended minerals and dissolved organic matter. Also, we included stations for which the bottom depth varied between a few meters and in access of $20 \mathrm{~m}$ i. e., with this choice we covered the bottom depth range within which the bottom optical impact should vary between very distinct and close to infinitesimal [Korosov et al., 2016]. At the same time, the locations of the chosen stations should be far enough from the coastline to exclude the interference of adjacency effect when applying MODIS-Aqua data.

Fig. 4 explicitly shows that at least for bottom depths under about $10 \mathrm{~m}$, the application of the BOREALI-OSW algorithm accounting for the bottom optical influence yields $\mathrm{CHL}$ values appreciably closer to those determined in the laboratory as compared to the $\mathrm{CHL}$ retrievals performed with the algorithms neglecting the bottom effect. At sites with greater bottom depths, the difference between the retrievals taking into account and neglecting the bottom optical impact progressively decreases, remaining however appreciable, thus giving additional evidence in favor of the application of the BOREALI-OSW algorithm.

Analyzing the algorithm performance in the case of satellite data processing, there are several factors that should be taken into account. First and foremost, the inaccuracy of atmospheric correction is subject to uncontrollable changes in the atmospheric aerosol composition over the target site. Secondly, the spatial resolution of MODIS-Aqua data is $1 \times 1 \mathrm{~km}$, which means that the heterogeneity of bottom depth and bottom cover as well as the spatial distribution of $\mathrm{CHL}$ inevitably differ from their counterparts inherent in the spot-like areas of the individual stations, with the results of which we straightforwardly compared the satellite data.

As should be expected, Fig. 4 also exhibits an appreciably higher accuracy of $\mathrm{CHL}$ retrievals from in situ radiometric measurements as compared to the spaceborne data processed with BOREALI-OSW. This is further illustrated in Fig. 5. Indeed, in situ radiometric measurements are not noised with imperfect atmospheric correction, and the data on bottom depth and type are far more accurate as they were directly determined just beneath the radiometer viewing the target spot. Besides, in the case of in situ radiometric measurements we were not limited by the adjacency effects and performed our measurements also close to the coastline including the points with low $\mathrm{CHL}$. We could also include the points from Saugatuck with relatively high $\mathrm{CHL}$ concentrations. In sum, these consolidated data permitted to draw 


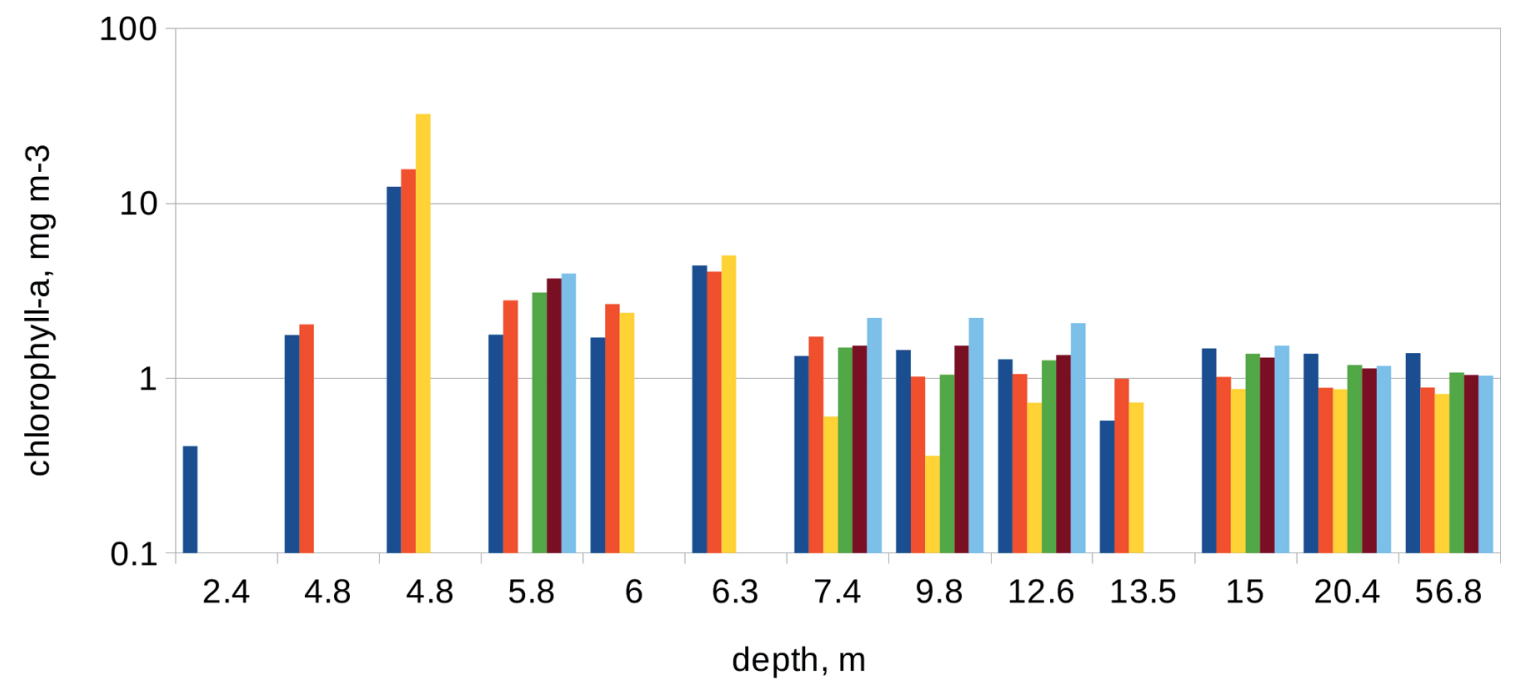

$\begin{array}{ll}\square \text { Lab Chlorophyll (ug/L) } & \text { RADIOMETER, OSW } \\ \square \text { MODIS, OSW } & \text { RADIOMETER } \\ \text { MODIS } & \text { OC4 }\end{array}$

Fig. 4. A cumulative comparison of $\mathrm{CHL}$ determinations performed at the laboratory and retrieved with the BOREALI-OSW algorithm from the in situ radiometric and spaceborne MODIS-Aqua data as well as the MODIS Aqua data processed with OC4 (i. e. neglecting the optical impact of the bottom)

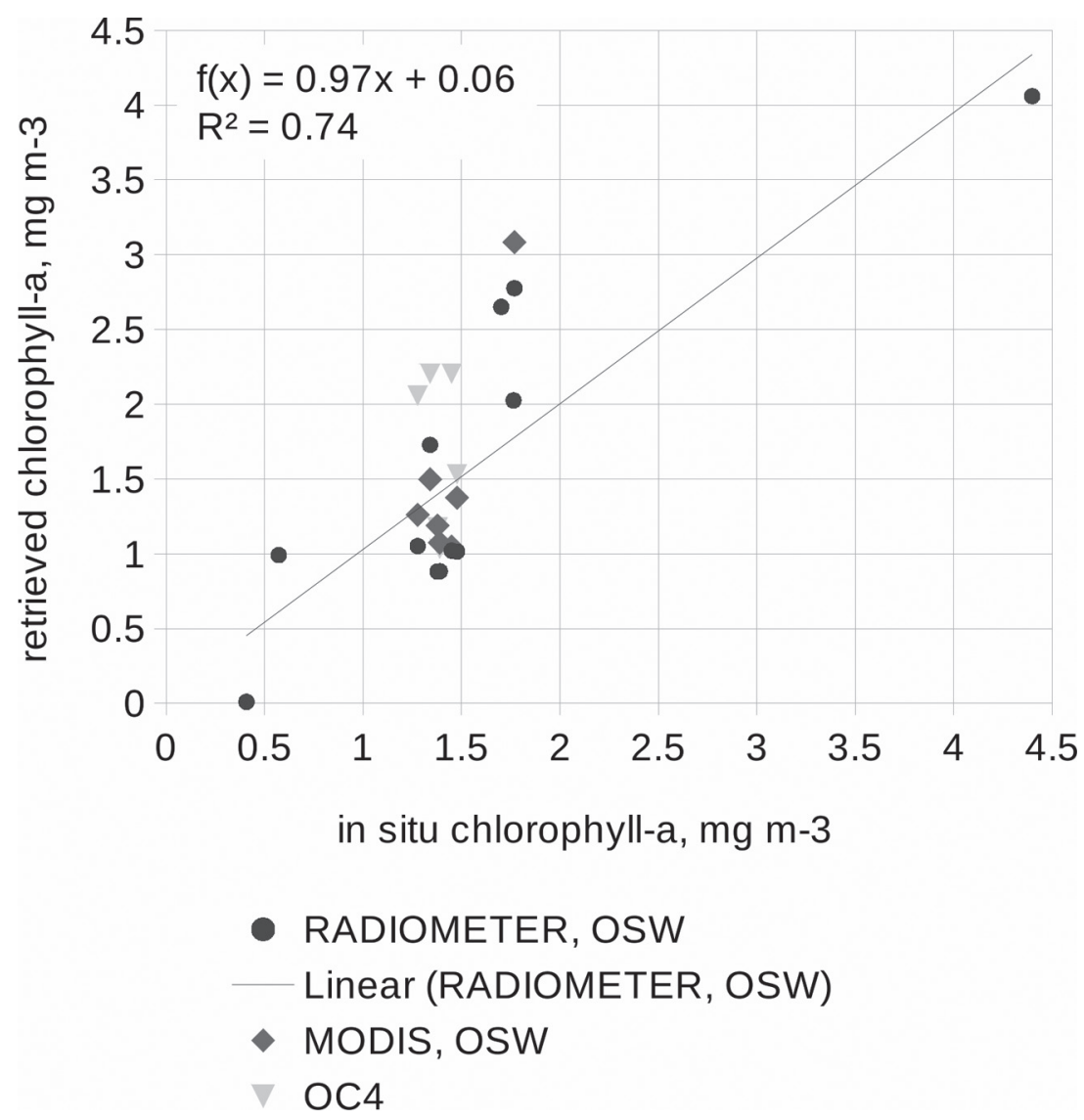

Fig. 5. A comparison of $\mathrm{CHL}$ values restored in the laboratory from water samples and retrieved from in situ radiometric, and MODIS-Aqua data with and without accounting for the bottom optical influence

the correlation line nearly crossing the origin of coordinates. This correlation line again shows very eloquently the advantage of application of the BOREALI-OSW algorithm. 

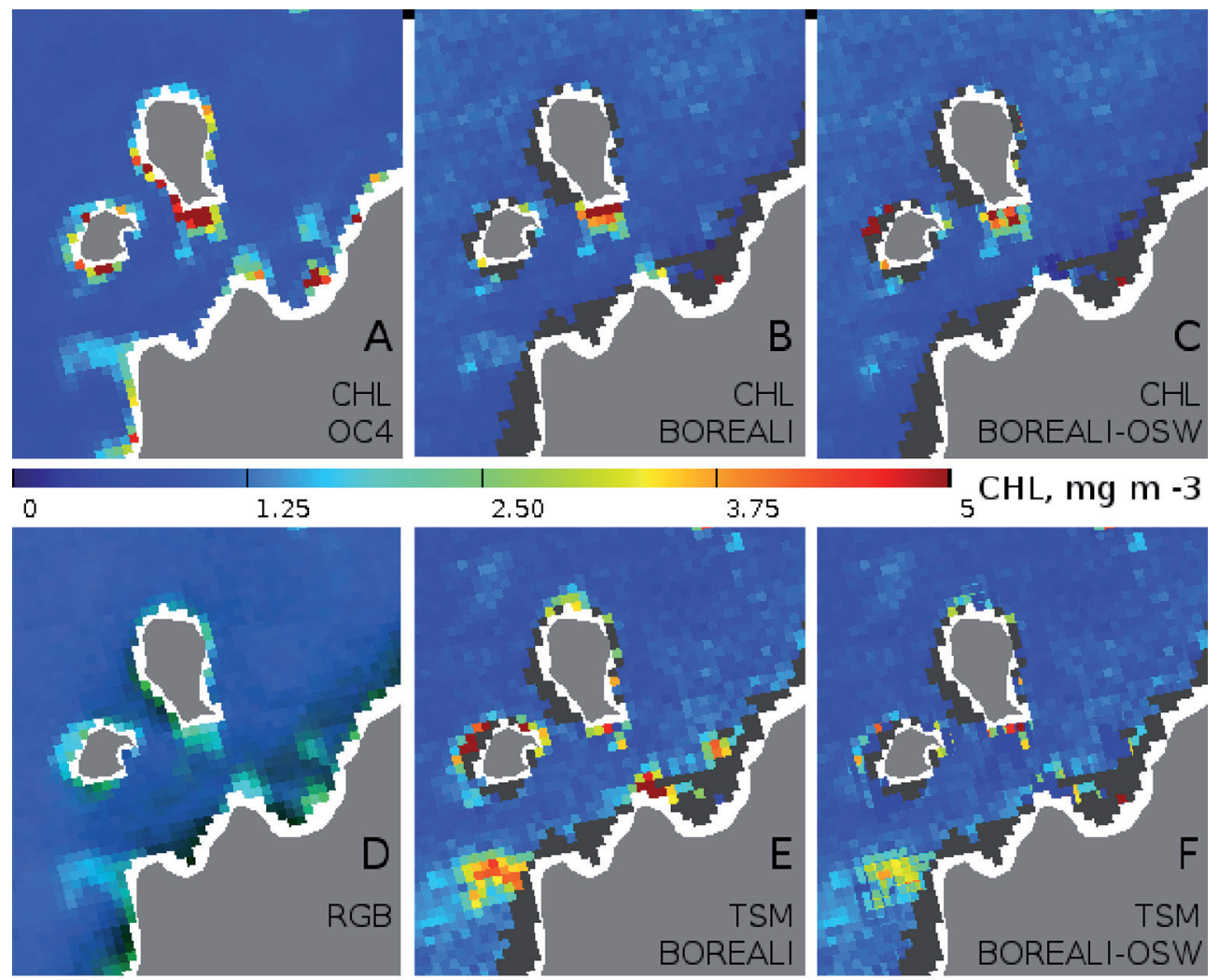

CHL, mg $\mathrm{m}-3$

0

0.03
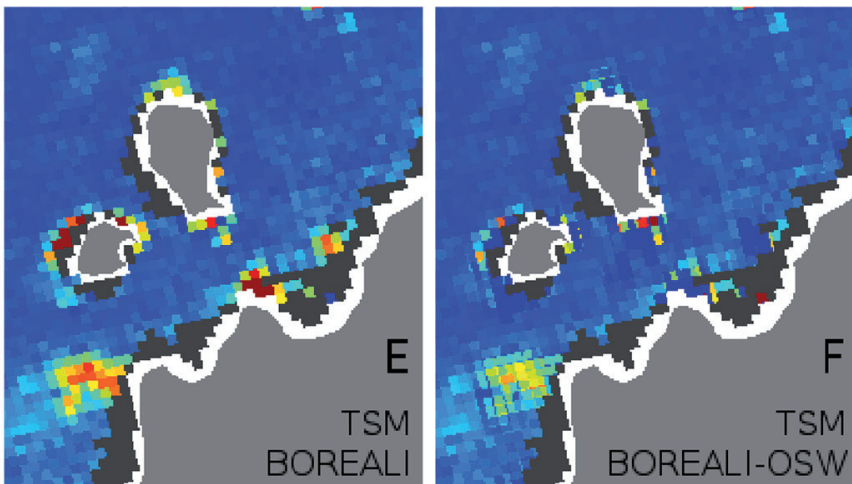

0.05

0.08

0.1

TSM, g $\mathrm{m}-3$

Fig. 6. Comparison of the spatial distribution of water quality parameters derived using various methods: A - CHL, standard NASA MODIS OC4 algorithm; B - CHL, BOREALI without bottom correction; C-CHL, BOREALI-OSW (i. e., with bottom correction); D - an RGB composite from 412, 555 and 670 bands; E - TSM, BOREALI without bottom correction; F - TSM, BOREALI-OSW (i. e., with bottom correction). Land is masked by light gray color, dark gray areas stand for negative pixels; white areas signify clouds or absence of data

Thus, notwithstanding all the aforementioned uncertainties associated with spaceborne data, the BOREALI-OSW generated CHL values are sensibly more accurate than the retrievals neglecting the bottom optical impact as compared for instance with the retrieval results performed with the standard OC4 algorithm.

\section{Discussion}

In the following discussion we are focusing on the results intended to meet the original objectives set up in the present study: development of a bio-optical retrieval algorithm for very clear / optically shallow waters [part I: Korosov et al., 2016], and assessment of its potentials as an operative tool for satellite-based monitoring of the coastal zone of Lake Michigan.

Correspondingly, such an algorithm, named BOREALI-OSW, and the respective code were elaborated. The BOREALI-OSW algorithm is based on the Levenberg-Marquardt multivariate optimization technique, a hydro-optical model established specifically for Lake Michigan, and a few parameterizations relating $(i)$ the bulk water column inherent optical properties (absorption and scattering) to the CPA concentration vector, $\boldsymbol{C}$ and (ii) the subsurface remote sensing reflectance to $\boldsymbol{C}$, bottom type and depth as well as the sun illumination conditions.

Assessing in general the performance of the developed code it can be defended that at least for bottom depths under ca. $10 \mathrm{~m}$ the application of the BOREALI-OSW algorithm accounting for bottom optical influence yields $\mathrm{CHL}$ values appreciably closer to those determined in the laboratory as compared to $\mathrm{CHL}$ retrievals performed with the algorithms neglecting the bottom effect. At sites with a greater bottom depth, the difference between the retrievals taking into account and neglecting the bottom optical impact progressively decreases, however it persists, thus giving additional evidence in favor of the application of the BOREALI-OSW algorithm.

When comparing in situ radiometric retrievals with BOREALI-OSW and respective MODIS data 

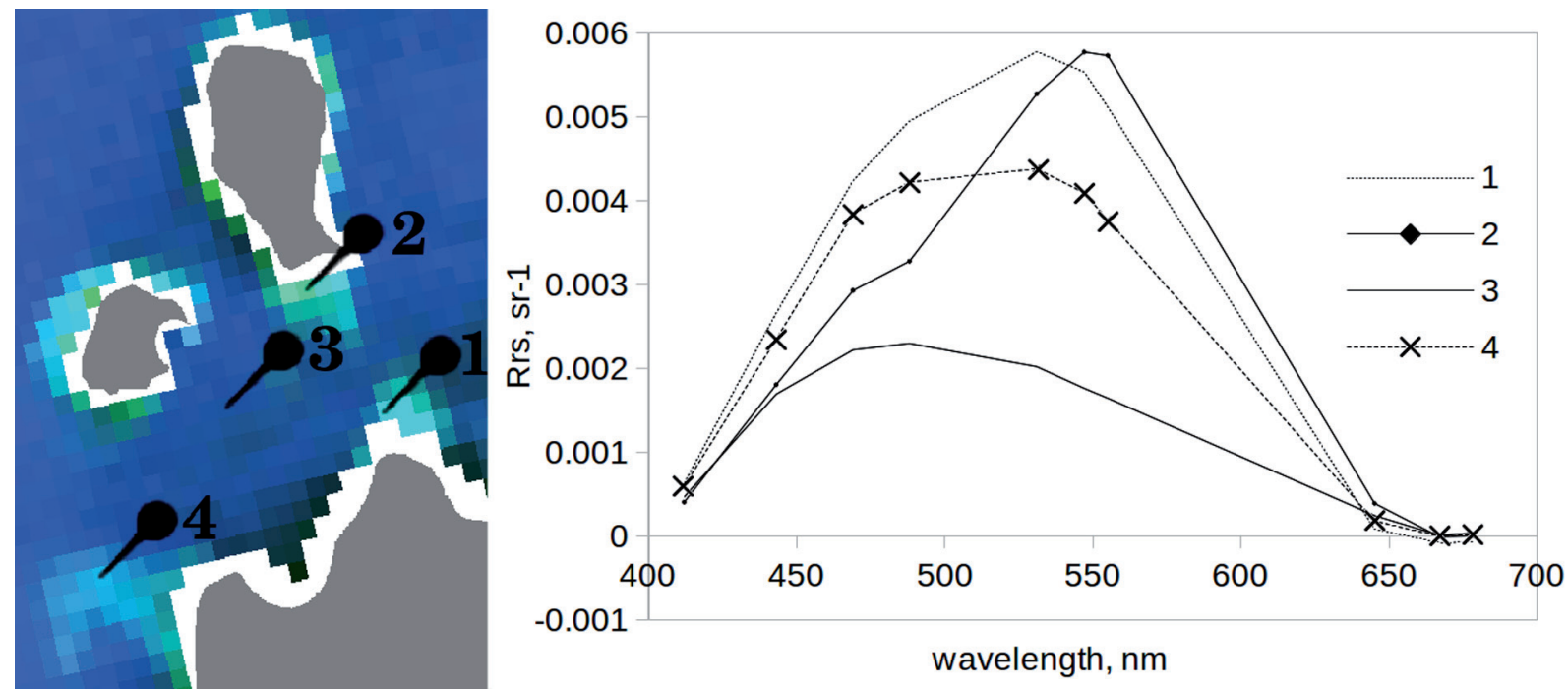

Fig. 7. Spectral values of remote sensing reflectance $R_{r s}$ measured by MODIS (right): 1 - shallow water with low CHL, 2 - shallow water with enhanced CHL, 3 - deep water with enhanced CHL, 4 - shallow water with enhanced TSM. Location of pixels is marked by pins on the RGB composite (left)

based retrievals it can be seen that the MODIS data processed with BOREALI-OSW exhibits an obvious advantage over the results obtained with BOREALI and especially with OC4 (see also the discussion below).

At the same time, the in situ radiometric retrievals of $\mathrm{CHL}$ rather frequently prove to be inferior to those provided from the MERIS data. This is thought to be due to the integrating capability of MODIS data (over $1 \times 1 \mathrm{~km}$ ) whereas the radiometer's field of view is so narrow that in the course of in situ radiometric measurements it can inadvertently (due to, e. g., even a slight boat displacement) capture the bottom spot with the optical properties other than recorded in the logbook.

As mentioned above, in the majority of cases the OC4 data are the least accurate (especially at SB stations) when compared to the retrievals by BOREALI-OSW and even by BOREALI. This can be further illustrated with the data from a few sites within the Sleeping Bear (SB) Area (Fig. 6) that have not been covered by in situ measurements, and hence for which neither CPA concentrations nor bottom properties were known.

The OC4 algorithm retrieved high $\mathrm{CHL}$ values at the southern tip of North Manitou Island as well as in the locations for which the optical signal is impacted either by the bottom (north of the Pyramid Point) or TSM (west of the SB site). Analysis of the spectral features of MODIS remote sensing reflectance, $R_{r S w}$ spectra (Fig. 7) used for CPA retrievals shows that the BOREALI-OSW algorithm performs better than BOREALI and especially than OC4.

Indeed, at the site located north off the Pyramid Point (Figs. 6 and 7, pin 1), $R_{r s}$ in the red
(648-678 nm) is very low and the reflectance in the green and blue $(412-555 \mathrm{~nm})$ is rather high, indicating that most of the signal comes from a highly reflective bottom and therefore is absorbed in the red by water per se. For the site indicated as pin 2 (Figs. 6 and 7 ), $R_{r s}$ in the red is rather high, suggesting that the light signal comes from the water column per se and not from the bottom. At the same time, $R_{r s}$ in the blue is rather low, which can be attributed to a significant presence of $\mathrm{CHL}$ in the water column. Therefore, it is indeed a case with enhanced $\mathrm{CHL}$ and a moderate bottom optical impact.

The site marked as pin 3 is located in deep waters. The $R_{r s}$ spectrum exhibits low values of reflection in the blue and some (although rather moderate) enhancement at $\sim 490 \mathrm{~nm}$. These spectral features are typical of waters rather rich in $\mathrm{CHL}$ and nearly void of suspended minerals [Bukata et al., 1995]

West of the SB site (Figs. 6 and 7, pin 4), $R_{r s}$ is high not solely in the red but also in the $450-$ $500 \mathrm{~nm}$ spectral region. It explicitly indicates that the upwelling signal originates in the water column rich in suspended minerals. Since $R_{r s}$ values in the blue are slightly lower than they are in the pin 1 case, it could be interpreted as a confident indication of low amounts of $\mathrm{CHL}$ in the presence of TSM.

Thus, returning to the results of MODIS data retrievals discussed above with regard to Fig. 6, it seems fully rightful to state that the retrieval results provided by BOREALI-OSW reflect more faithfully the hydro-optical situations inherent in the target locations. 
Thus, based on both the results of the forward and inverse problem simulations performed in this study it appears completely justified to state that the developed BOREALI-OSW and respective operational code present a tool for monitoring optically shallow/transparent waters. In the present paper the faculties of the tool are exemplified for Lake Michigan as we used the hydro-optical model inherent in this water body. However, the developed tool is not specific in terms of the nature of waters. Therefore, we see no essential impediments for extending the use of the developed tool also to other inland and marine aquatic environments or their specific areas for which the water clarity and bottom reflection present a challenge to keep track of changes in the trophy/ecological state employing the present and forthcoming satellite sensors.

\section{Conclusions}

In attacking the problem of remote sensing of optically shallow waters with the purpose of retrieving concentrations of CPAs against the background of the light signal originating from bottom reflections, we pursued two avenues. Firstly, by means of forward simulations we analyzed through the spectral signature variations of subsurface remote sensing reflectance, $R_{r s w}$ the modifications of the upwelling signal (controlled by the bottom type and depth). Then we passed to inverse problem simulations in order to test the sensitivity of our calculations of CPA concentrations to possible excursions of the input parameters such as bottom depth, bottom type, and measured spectral values of subsurface remote sensing reflectance, $R_{\text {rswToT: }}$. To do that, we developed a retrieval algorithm (BOREALI-OSW) dedicated specifically to coping with optically shallow waters.

Secondly, we applied the developed algorithm to process both in situ radiometric and satellite data from stations at which in situ measurements of CHL were run concurrently with, respectively, in situ radiometric measurements and satellite overflights.

To achieve the forward problem solution, we employed the hydro-optical model inherent in Lake Michigan water, and considered the bottom types encountered in this water body, viz. silicon sand, Cladophora/Chara, limestone rocks, and silt.

Our simulations have shown that even at very low CPA concentrations (less than 0.01 in respective units) the optical influence of the bottom becomes indiscernible if the bottom depth, $H$ approaches $20 \mathrm{~m}$. In waters containing total suspended matter (TSM) in quantities of about $0.5 \mathrm{~g} / \mathrm{m}^{3}$ (while $\mathrm{CHL}$ and colored dissolved organic matter, CDOM remain infinitesimal) the bottom optical influence ceases at $H$ slightly above $10 \mathrm{~m}$. An analogous critical value of $H$ was found if $a_{C D O M}$ is $0.5 \mathrm{~m}^{-3}$, while $\mathrm{CHL}$ and TSM are infinitesimal.

The noise sensitivity analysis has shown that the shallower water column and the higher bottom albedo the more significant is the ensuing error in CPA retrievals. However, even in the case of a sandy bottom and a water column of $5 \mathrm{~m}$, a $10 \%$ error in determining its albedo leads to a 18 , 28 and $10 \%$ error in retrieving, respectively, CHL, TSM and CDOM. In the case of deeper waters $(H=10 \mathrm{~m})$ the noise in all considered CPA retrievals becomes lower than 4, 10 and $4 \%$ for $\mathrm{CHL}$, TSM and CDOM, respectively.

Our analysis of the dependence of normalized root mean square error, $\tilde{E}$ in CPA concentration determinations on the noise level in input values of bottom depth, $H$ and bottom albedo, $A$ has shown that $\tilde{E}$ values can reach $18, \sim 30$ and $10 \%$ for $\mathrm{CHL}$, TSM and CDOM, respectively, if the noise in $H$ is $10 \%$, but they become much higher $(55,55$ and $17 \%$ for CHL, TSM and CDOM, respectively) if the noise in $A$ is $10 \%$.

Our numerical assessment of the BOREALIOSW algorithm performance in real conditions of Lake Michigan convincingly shows that at least for bottom depths less than $10 \mathrm{~m}$ its application to in situ radiometric data yields $\mathrm{CHL}$ values appreciably closer to those determined in the laboratory as compared to $\mathrm{CHL}$ retrievals performed with the algorithms neglecting the bottom effect. At sites with greater bottom depths, the difference between the retrievals taking into account and neglecting the bottom optical impact progressively decreases, however, remains appreciable, thus giving additional evidence in favor of the application of the BOREALI-OSW algorithm.

The application of the BOREALI-OSW algorithm to MODIS-Aqua data from Lake Michigan yielded less accurate retrievals of $\mathrm{CHL}$ as compared to those obtained from in situ radiometric measurements. However, they prove to be appreciably closer compared to the tested procedures that neglect the bottom optical influence. The reasons for a less accurate performance of the BOREALI-OSW algorithm with space-borne data are at least threefold. First and foremost, the reason resides in the inaccuracy of atmospheric correction, which is subject to uncontrollable variations in the atmospheric aerosol composition over the target site. Secondly, the spatial resolution of MODIS-Aqua data is $1 \times 1 \mathrm{~km}$. It means that the heterogeneity of bottom depth and bottom cover as well as the spatial distribution of $\mathrm{CHL}$ inevitably differ from their counterparts inherent in the spot-like areas of the individual stations, with the results of which we straightforwardly compare the spaceborne data. Thirdly, although diurnal variability of epilimnetic $\mathrm{CHL}$ under 
low wind conditions in summer generally remains within $10 \%$ [Fee, 1976; Fahnenstiel and Scavia, 1987], the given time difference between satellite and in situ measurements (up to 3-4 hours) may contribute to the observed discrepancy between satellite and in situ measurements.

It can be foreseen that with the development of more precise bathymetric and bottom type maps within the coastal zone, the application of the BOREALI-OSW algorithm will also yield more accurate CPA retrievals. However, none of the improvements mentioned above will be able not only to nullify but even to diminish the problem of correct assessment of the path radiance. Undoubtedly, the imprecision of the atmospheric correction remains a stumbling-block, and the major efforts need to be undertaken in this direction.

Nevertheless, notwithstanding the aforementioned uncertainties associated with space-borne data, we have shown that the BOREALI-OSW generated $\mathrm{CHL}$ values are sensibly more accurate than the retrievals neglecting the bottom optical impact, and the developed ocean color data processing tool solidly presents enhanced opportunities for monitoring optically shallow aquatic environments.

Finally, with the availability of required input data, and a judicious consideration of the limitations revealed in our simulations, the BOREALIOSW algorithm is certainly applicable to remote ecological inspections of a large variety of coastal marine and lacustrine waters given the appropriate hydro-optical models.

This investigation was supported by NASA Roses Grant \# NNX09AU88G and Michigan Tech Research Institute Internal Research and Development.

\section{References}

Bukata R., Jerome J., Kondratyev K., and Pozdnyakov $D$. Optical properties and pemote sensing of inland

\section{СВЕДЕНИЯ ОБ АВТОРАХ:}

\section{Коросов Антон Андреевич}

научный сотрудник, руководитель группы дистанционного зондирования морского и материкового льда, к. Ф.-м. н. Центр по окружающей среде и дистанционному зондированию имени Нансена,

Берген, Норвегия

эл. почта: anton.korosov@nersc.no and coastal waters. Boca Raton: CRC Press, 1995. $362 \mathrm{p}$.

EEGLE ship-collected data archive. 2003. 1, 2. CD-ROM.

Fahnenstiel G. L., Scavia D. Dynamics of Lake Michigan phytoplankton: the deep chlorophyll layer. Journal of Great Lakes Research. 1987. Vol. 13, no. 3 P. 285-295. doi: 10.1016/S0380-1330(87)71652-9

Fee E. J. The vertical and seasonal distribution of chlorophyll in lakes of the Experimental Lakes Area, northwestern Ontario: implications for primary production estimates. Limnology and Oceanography. 1976. Vol. 21, no. 6. P. 767-783.

Hooker S. B., Zibordi G. Advanced methods for characterizing the immersion factor of irradiance sensors. J. Atmos. Oceanic Technol. 2005. Vol. 22. P. 757770. doi: $10.1175 / \mathrm{JTECH} 1736.1$

Korosov A. A., Pozdnyakov D. V., Folkestad A., Pettersson L. H., Sörensen K., Shuchman R. Semi-empirical algorithm for the retrieval of ecology-relevant water constituents in various aquatic environments. Algorithms. 2009. Vol. 2. P. 470-497.

Korosov A. A., Pozdnyakov D. V., Shuchman R., Sayers M., Sawtell R., Moiseev A. V. Bio-optical retrieval algorithm for the optically shallow waters of Lake Michigan. I. Model description and sensitivity/robustness assessment. Trans. KarRC RAS. 2017. No. 3. P. 79-92. doi: $10.17076 / \lim 473$

Shuchman R. A., Leshkevich G., Sayers M. J., Johengen T. H., Brooks C. N., Pozdnyakov D. An algorithm to retrieve chlorophyll, dissolved organic carbon, and suspended minerals from Great Lakes satellite data. Journal of Great Lakes Research. 2013. Vol. 32. P. 14-33.

Shuchman R., Korosov A., Hatt C., Pozdnyakov D., Means J., Meadows G. Verification and application of a bio-optical algorithm for Lake Michigan using SeaWIFS: a 7-year inter-annual analysis. Journal of Great Lakes Research. 2006. Vol. 32. P. 258-279.

Zibordi G. Immersion factor of in-water radiance sensors: assessment for a class of radiometers. J. At mos. Oceanic Technol. 2006. Vol. 23. P. 302-313. doi: 10.1175/JTECH1847.1

Received June 29, 2017

\section{CONTRIBUTORS:}

Korosov, Anton

Nansen Environmental and Remote Sensing Center Thormøhlens gate, 47, N-5006, Bergen, Norway

e-mail: anton.korosov@nersc.no 
Поздняков Дмитрий Викторович

заместитель директора по науке,

руководитель группы водных экосистем

д. Ф.-м. н., проф.

Научный фонд «Международный центр по окружающей

среде и дистанционному зондированию имени Нансена»

14-я линия В. О., 7, оф. 49, Санкт-Петербург, Россия,

199034

эл. почта: dmitry.pozdnyakov@niersc.spb.ru

\section{Шухман Роберт}

директор, PhD

Мичиганский технический исследовательский институт

Анн-Арбор, США

эл. почта: shuchman@mtu.edu

\section{Сэйерс Майкл}

научный сотрудник

Мичиганский технический исследовательский институт

Анн-Арбор, США

эл. почта: mjsayers@mtu.edu

\section{Сотелл Рэйд}

научный сотрудник

Мичиганский технический исследовательский институт

Анн-Арбор, США

эл. почта: rwsawtel@mtu.edu

\section{Моисеев Артем Владимирович}

младший научный сотрудник

Научный фонд «Международный центр по окружающей среде и дистанционному зондированию имени Нансена» 14-я линия В. О., 7, оф. 49, Санкт-Петербург, Россия, 199034

эл. почта: artem.moiseev@niersc.spb.ru

\section{Pozdnyakov, Dmitry}

Scientific foundation "Nansen International Environmental and Remote Sensing Centre"

14th Line, 7, Office 49, Vasilievsky Island, 199034 St.

Petersburg, Russia

e-mail: dmitry.pozdnyakov@niersc.spb.ru

\section{Shuchman, Robert}

Michigan Tech Research Institute

3600 Green Court, Suite 100, MI 48105 Ann Arbor, USA

e-mail: shuchman@mtu.edu

Sayers, Michael

Michigan Tech Research Institute

3600 Green Court, Suite 100, MI 48105 Ann Arbor, USA

e-mail: mjsayers@mtu.edu

\section{Sawtell, Reid}

Michigan Tech Research Institute

3600 Green Court, Suite 100, MI 48105 Ann Arbor, USA

e-mail: rwsawtel@mtu.edu

\section{Moiseev, Artem}

Scientific foundation "Nansen International Environmental and Remote Sensing Centre"

14th Line, 7, Office 49, Vasilievsky Island, 199034 St.

Petersburg, Russia

e-mail: artem.moiseev@niersc.spb.ru 